\title{
Latin American Political Culture and Citizenship Norms
}

\author{
Daniel Miranda, Catalina Miranda, and Loreto Muñoz
}

\begin{abstract}
Latin American countries have a history of democracies interrupted by political unrest, civil war, human rights abuses, and military dictatorships. In the region, there have been several attempts to establish representative governments throughout the last decade, especially in post-dictatorship periods. However, scholars have questioned the quality of these achieved regimes, especially regarding their democratic quality. To what extent do democratic ideals coexist with authoritarian ideas? This chapter explores the extent to which support for authoritarian government practices is associated with different types of citizenship norms and evaluates the role of civic knowledge. Using a series of regression models with clustered errors, and data from Latin American countries in IEA's International Civic and Citizenship Education Study (ICCS) 2016, both the role of citizenship norms and civic knowledge in explaining students' support for authoritarian practices were analyzed. The results indicate that, in Latin America, there exists a significant level of support for authoritarian ideas in younger age groups, which is consistent with previous research focused on the adult population. Additionally, results indicate that those students classified in duty-based and comprehensive citizenship profiles show higher levels of support for authoritarian practices. In contrast, students with monitorial and anomic profiles are less likely to support these types of practices. Finally, civic knowledge protects young people from authoritarian ideas and moderates the effect of different conceptions of citizenship norms. Results highlight the relevance of education for democratic citizenship, which could help on the legitimacy of the democratic system.
\end{abstract}

D. Miranda ( $\square)$

Centro de Medición MIDE UC, Pontifica Universidad Católica de Chile, Santiago, Chile

e-mail: damiran1@uc.cl

C. Miranda

Centro de Estudios de Políticas y Prácticas en Educación (CEPPE-UC), Pontificia Universidad

Católica de Chile, Santiago, Chile

e-mail: ccmiranda@uc.cl

L. Muñoz

Datavoz, Santiago, Chile

e-mail: loreto.munoz@datavoz.cl

(C) International Association for the Evaluation of Educational Achievement (IEA) 2021

E. Treviño et al. (eds.), Good Citizenship for the Next Generation,

International Association for the Evaluation of Educational Achievement (IEA)

Research for Education 12, https://doi.org/10.1007/978-3-030-75746-5_6 
Keywords Citizenship norms - Political culture - Authoritarianism - International Civic and Citizenship Education Study (ICCS)

\section{Introduction}

Democracy as a system of government operates under a series of principles that must be supported by its citizens. According to Sartori (1999), as a political regime, democracy is an ideal that must be promoted and believed by citizens. In this sense, an important challenge is for members of society to support and legitimize those central principles so that the political system works, and those ideas that erode its foundations have minimum expression. The issue of the legitimacy of democracy rests on the support of citizens who sustain a belief system consistent with the existing political institutions or, more specifically, citizens who adhere to a value system allowing the peaceful "play" of power (Lipset 1959). That is to say, there is a political culture consistent with democratic institutions.

Among the most severe threats to the democratic ideal is the existence of attitudes that validate authoritarian leaders or governments (Altemeyer 2008; Dewey 1989). These kinds of threats are particularly evident in Latin America, with its long history of democracies interrupted by political unrest, civil war, human rights abuses, and military dictatorships. Today, several countries in the region are experiencing democratic crises, such as Venezuela, which has endured turbulent years of authoritarian crisis, Brazil with the election of a president who openly justifies the military dictatorships of the 1970s, and Peru with the dissolution of parliament in October 2019.

In contrast, there have been several attempts to consolidate representative regimes throughout the region, especially in post-dictatorship periods. However, these attempts seem rather incomplete, because consolidating a democracy does not finish with establishing the election of political leaders, it also requires guaranteeing civil liberties as well (Haynes 2003; O’Donell 1994). The democratization efforts have brought democratic ideas to the forefront as a priority for various governments in the region, which implies that Latin American citizens have changing views of what it means to be a good citizen, and these conceptions of citizenship could play a role in shaping beliefs about the role of authoritarian practices.

The International Civic and Citizenship Education Study (ICCS) 2016, conducted by the International Association for the Evaluation of Educational Achievement (IEA), recognizes the different characteristics of Latin American countries, conducting specific surveys that evaluate students' attitudes and perceptions (Schulz et al. 2010, 2018a, 2016), including their endorsement of authoritarian government practices. Given this unique opportunity, this chapter explores the following questions: To what extent do democratic ideals coexist with authoritarian ideas? Can a particular pattern be identified in the younger generations? This chapter examines the extent to which support for authoritarian government practices is associated with different types of citizenship norms and evaluates the role of civic knowledge. 


\section{Theoretical Framework}

The legitimacy of democracy rests on the support of citizens and a system of beliefs consistent with existing political institutions (Lipset 1959). This assumption implies that society must be able to "generate and maintain" beliefs consistent with this form of government and reject those beliefs deemed to be inconsistent. Along these lines, support for authoritarian practices or the justification of a dictatorship could threaten the legitimacy of democracy.

Latin American democracies tend to undermine the system of values that allows the peaceful play of power (Lipset 1959). This stigma is reflected in that a nonignorable portion of the population adheres to some form of authoritarianism. The 2015 Human Development Report in Chile shows that, although authoritarianism endorsement has declined, a significant proportion of Chileans (19\% in 1999 and $15 \%$ in 2013) consider that "in some circumstances, an authoritarian government is preferable to a democratic one" and that "people like you do not care whether the government is democratic or authoritarian" (31\% in 1999 and 14\% in 2013) (PNUD 2015). Moreover, support for authoritarian governments is even more substantial in other Latin American countries.

Authoritarian political culture could be understood as patterns of behavior (Almond and Verba 1989) of leaders or governments that are at odds with democratic principles, such as closing the parliament or censoring the media when facing a conflict. The idea of authoritarian political culture is related to the old concept of authoritarianism initially understood as personality (Adorno et al. 1950) and later as a collection of social attitudes that support legitimate authorities (Altemeyer 1996, 2008). A widely contested idea is that those authoritarian beliefs are an essential part of the political culture in Latin America (Booth and Seligson 1984; Lagos 2003; Seligson and Booth 1993). This chapter aims to contribute to this discussion by analyzing the literature related to citizenship norms.

The hope of the renewal of politics and democracy lies in the new generations. To contribute to this debate, ICCS 2009 and 2016 asked the same question about authoritarian/democratic beliefs to a similar sample of grade 8 students. Considering the statement that "dictatorships are justified when they bring economic benefits," the percentage of young people who would support a dictatorship decreased by $8 \%$ between 2009 and 2016. Additionally, the Latin American report indicates that those students with higher levels of civic knowledge are less likely to support authoritarian practices (Schulz et al. 2018a). This result is a good starting point for analyzing authoritarian political culture as seen by young students in Latin America.

The existence of citizenship norms is relevant because they shape attitudes and behaviors (Bolzendahl and Coffé 2013; Coffé and van der Lippe 2010; Heijden 2014; Jennings 2015). The study of views or concepts of citizenship assumes a certain consistency between norms and the attitudes/behavior of citizens (Almond and Verba 1989). In the words of Professor van Deth, "those who support the idea that citizens have a duty to cast a vote will be much more likely to participate in an election than other people" (2007, p. 2). In this vein, the extent to which support 
for citizenship norms correlates with authoritarian ideas appears to be a legitimate question, considering that this is still an unexplored link.

Given the absence of evidence that links citizenship norms with authoritarian beliefs, making connections with different types of participation could be useful to test some exploratory hypotheses. First, people with duty-based or higher normative profiles, characterized by belief in traditional duties (such as voting), are less likely to participate in contentious political activities and are more willing to participate in traditional activities (Bolzendahl and Coffé 2013; Dalton 2015). Thus, since these types of norms are related to conventional attitudes, students with higher normative support could be expected to endorse more authoritarian ideas. Nevertheless, involvement in conventional activities does not imply authoritarian ideas. In the same vein, yet with different arguments, we could expect that antidemocratic ideas may coexist with democratic conceptions of citizenship, which could imply high support for authoritarian practices in profiles oriented to democracy (Stevens et al. 2006). However, the opposite scenario is uncertain. Do people that do not endorse citizenship norms subscribe to authoritarian ideas? In this chapter, we aim to contribute to political culture research in Latin America by shedding more light on the potential associations between citizenship norms and authoritarian beliefs in five Latin America countries participating in ICCS 2016.

\section{Data and Methods}

\subsection{Data and Variables}

The data analyzed is obtained from IEA's ICCS 2016 (Schulz et al. 2018a). The ICCS study was undertaken with a sample of more than 90,000 grade 8 students from 24 countries (Schulz et al. 2018a). The analysis considers the five Latin American countries that participated in ICCS 2016: Chile, Colombia, the Dominican Republic, Mexico, and Peru.

The dependent variable of this study is an item response theory (IRT) generated score; over 11 items are related to authoritarian government practices (Table 1). These scores are weighted least estimates (WLE) of the IRT fitted model and express the varying degrees of students' endorsement of authoritarian government practices. It presents an international mean of 50 points, and a standard deviation of 10 for equally weighted countries (Schulz et al. 2018b).

The first variable contains the most likely latent classes for each student according to their conception of citizenship norms. Five profiles were generated (see Chap. 3): comprehensive students who show higher support for all evaluated citizenship norms; duty-based students who support mainly traditional norms; socially-engaged students who mainly support norms oriented to helping the community; monitorial students who show mid-lower support for all norms; and, finally, anomic students who express very low support for all citizenship norms. 
Table 1 Dependent variable: Support for authoritarian government practices scale and its items

\begin{tabular}{|c|c|}
\hline Item & Response scale \\
\hline $\begin{array}{l}\text { How much do you agree or disagree with the following statements about } \\
\text { the government and its leaders? } \\
\text { LS3G01A: It is better for government leaders to make decisions without } \\
\text { consulting anybody }\end{array}$ & \multirow[t]{11}{*}{$\begin{array}{l}\text { - Strongly agree } \\
\text { - Agree } \\
\text { - Disagree } \\
\text { - Strongly disagree }\end{array}$} \\
\hline $\begin{array}{l}\text { LS3G01B: People in government must enforce their authority even if it } \\
\text { means violating the rights of some citizens }\end{array}$ & \\
\hline $\begin{array}{l}\text { LS3G01C: People in government lose part of their authority when they } \\
\text { admit their mistakes }\end{array}$ & \\
\hline $\begin{array}{l}\text { LS3G01D: People whose opinions are different than those of the } \\
\text { government must be considered its enemies }\end{array}$ & \\
\hline $\begin{array}{l}\text { LS3G01E: The most important opinion of a country should be that of } \\
\text { the president }\end{array}$ & \\
\hline $\begin{array}{l}\text { LS3G01F: It is fair that the government does not comply with the law } \\
\text { when it thinks it is not necessary }\end{array}$ & \\
\hline $\begin{array}{l}\text { How much do you agree or disagree with the following statements about } \\
\text { governments and their power? } \\
\text { LS3G02A: Concentration of power in one person guarantees order }\end{array}$ & \\
\hline $\begin{array}{l}\text { LS3G02B: The government should close communication media that are } \\
\text { critical }\end{array}$ & \\
\hline $\begin{array}{l}\text { LS3G02C: If the president does not agree with }<\text { Congress }>\text {, he/she } \\
\text { should }<\text { dissolve }>\text { it }\end{array}$ & \\
\hline $\begin{array}{l}\text { LS3G02D: Dictatorships are justified when they bring order and safety } \\
(*)\end{array}$ & \\
\hline $\begin{array}{l}\text { LS3G02E: Dictatorships are justified when they bring economic benefits } \\
(*)\end{array}$ & \\
\hline $\begin{array}{l}\text { L_AUTGOV: Students' endorsement of authoritarian government } \\
\text { practices }\end{array}$ & Mean $=50 / \mathrm{SD}=10$ \\
\hline
\end{tabular}

Notes $(*)=$ Excluded items in the scale L_AUTGOV, SD = Standard deviation

Source ICCS 2016 user guide (Köhler et al. 2018)

Civic knowledge scores are IRT generated scores, using the responses to the 79 items from the ICCS test. This variable has an international average of 500 points and a standard deviation of 100 . We included two sets of variables for students' socioeconomic background: educational level and cultural capital. Family educational level is represented in five standardized levels (Schneider 2008), while cultural capital is measured by the number of books in each household. Finally, the student's gender is included as a control variable (Table 2). 
Table 2 Independent variables

\begin{tabular}{|c|c|}
\hline Item & Response \\
\hline Latent class of conceptions of citizenship norms & $\begin{array}{l}\text { Comprehensive } \\
\text { Duty-based } \\
\text { Socially engaged } \\
\text { Monitorial } \\
\text { Anomic }\end{array}$ \\
\hline \multicolumn{2}{|l|}{$\begin{array}{l}\text { Civic knowledge scale } \\
\text { IRT plausible values [one plausible value: (PV1CIV)] }\end{array}$} \\
\hline \multicolumn{2}{|l|}{ Control variables } \\
\hline $\begin{array}{l}\text { Family education } \\
\text { What is the highest level of education completed by your } \\
\text { male or female guardian? }\end{array}$ & $\begin{array}{l}\text { 5. Complete college or postgraduate } \\
\text { 4. Technical complete } \\
\text { 3. Secondary complete } \\
\text { 2. Grade } 8 \text { complete } \\
\text { 1. Not finished grade } 8\end{array}$ \\
\hline $\begin{array}{l}\text { Home literacy (number of books at home) } \\
\text { Approximately, how many books are at your home? }\end{array}$ & $\begin{array}{l}\text { 1. } 0-10 \\
\text { 2. } 11-100 \\
\text { 3. } 101-200 \\
\text { 4. } \text { More than } 200 \text { books }\end{array}$ \\
\hline Student gender & $\begin{array}{l}\text { 1. Girls } \\
\text { 0. Boys }\end{array}$ \\
\hline
\end{tabular}

Source ICCS 2016 user guide (Köhler et al. 2018)

\subsection{Methods}

The analysis was carried out using OLS (ordinal least square) linear regressions with clustered errors estimation and considering the total weight in all models across the five Latin American countries. Given that the ICCS 2016 sample nests students within schools, the estimation of standard errors considers that the observations within schools are non-independent. Two models were used to study the association of variables to students' endorsement of authoritarian government practices. Model 1 uses a dummy variable that grouped students according to their citizenship normative profiles: comprehensive (as the reference group), duty-based, socially engaged, monitorial, and anomic. Additionally, civic knowledge was entered as a predictor (only one plausible value), along with control variables (gender, parents' education, and number of books at home). Model 2 added four interaction terms to assess the role of civic knowledge in moderating the observed differences in support for authoritarian practices among conceptions of citizenship. Finally, to simplify the interpretation of the results, we estimated the predicted values of support for authoritarian practices for different levels of civic knowledge. All analysis was performed in Stata 14 (Statacorp 2016). 


\section{Results}

The following section is organized into two parts. The first describes the results of the 11 authoritarian government practices included in ICCS 2016. In the second, we describe the role of students' citizenship profiles and civic knowledge to explain their support for authoritarian practices.

\subsection{Support for Authoritarian Government Practices: Descriptive Patterns}

On average, 0.41 of students support authoritarian practices (agree/strongly agree). Chilean students show the lowest level of support (0.32), while the Dominican Republic has the highest (0.52). These initial results are a good representation of the support for authoritarian ideas in Latin America. Overall, at least one third of students in the region support authoritarian practices (Table 3).

Considering the set of 11 authoritarian practices evaluated, the two statements "It is better for government leaders to make decisions without consulting anybody" and "People whose opinions are different than those of the government must be considered its enemies" received the lowest support ( 0.22 on average). In Colombia and Chile, $0.12-0.13$ and $0.14-0.15$ of students, respectively, support these statements compared to over 0.20 of students in Peru, Mexico, and the Dominican Republic. Meanwhile, on average, between 0.45 and 0.57 of students in the region support the statements: "People in government lose part of their authority when they admit their mistakes," "The most important opinion of a country should be that of the president," and "Concentration of power in one person guarantees order," with students from Chile and Colombia showing the lowest support, and students in Mexico, Peru, and the Dominican Republic giving the highest support.

It is important to highlight that the percentage of support for statements directly related to dictatorships is particularly high. For example, the statements "Dictatorships are justified when they bring order and safety" and "Dictatorships are justified when they bring economic benefits," received support of 0.69 and 0.67 of students, on average, respectively. Even in the case of Chile, the country where students generally show the lowest level of support for authoritarian practices, support for these statements is above $50 \%$. It is important to mention that these statements have characteristics of double-barreled questions (Gehlbach 2015), which makes the responses difficult to interpret. Do students support dictatorships and/or their economic benefits? Do students support dictatorships and/or the order and security they are expected to bring? As such, responses to these statements need to be interpreted with caution. 
Table 3 Distribution of "agree/strongly agree" with authoritarian government practices

\begin{tabular}{|c|c|c|c|c|c|c|}
\hline & Chile & Colombia & $\begin{array}{l}\text { Dominican } \\
\text { Republic }\end{array}$ & Mexico & Peru & All countries \\
\hline $\begin{array}{l}\text { It is better for } \\
\text { government leaders to } \\
\text { make decisions without } \\
\text { consulting anybody }\end{array}$ & 0.14 & 0.13 & 0.31 & 0.26 & 0.20 & 0.22 \\
\hline $\begin{array}{l}\text { People in government } \\
\text { must enforce their } \\
\text { authority even if it means } \\
\text { violating the rights of } \\
\text { some citizens }\end{array}$ & 0.23 & 0.22 & 0.37 & 0.30 & 0.31 & 0.28 \\
\hline $\begin{array}{l}\text { People in government } \\
\text { lose part of their } \\
\text { authority when they } \\
\text { admit their mistakes }\end{array}$ & 0.35 & 0.46 & 0.64 & 0.53 & 0.52 & 0.51 \\
\hline $\begin{array}{l}\text { People whose opinions } \\
\text { are different than those } \\
\text { of the government must } \\
\text { be considered its enemies }\end{array}$ & 0.15 & 0.12 & 0.29 & 0.25 & 0.18 & 0.22 \\
\hline $\begin{array}{l}\text { The most important } \\
\text { opinion of a country } \\
\text { should be that of the } \\
\text { president }\end{array}$ & 0.38 & 0.50 & 0.69 & 0.41 & 0.56 & 0.45 \\
\hline $\begin{array}{l}\text { It is fair that the } \\
\text { government does not } \\
\text { comply with the law } \\
\text { when it thinks it is not } \\
\text { necessary }\end{array}$ & 0.21 & 0.21 & 0.38 & 0.29 & 0.28 & 0.27 \\
\hline $\begin{array}{l}\text { Concentration of power } \\
\text { in one person guarantees } \\
\text { order }\end{array}$ & 0.44 & 0.54 & 0.74 & 0.56 & 0.63 & 0.57 \\
\hline $\begin{array}{l}\text { The government should } \\
\text { close communication } \\
\text { media that are critical }\end{array}$ & 0.22 & 0.20 & 0.36 & 0.32 & 0.29 & 0.29 \\
\hline $\begin{array}{l}\text { If the president does not } \\
\text { agree with }<\text { Congress }> \\
\text { he/she should }<\text { dissolve }> \\
\text { it }\end{array}$ & 0.35 & 0.31 & 0.49 & 0.39 & 0.43 & 0.38 \\
\hline $\begin{array}{l}\text { Dictatorships are } \\
\text { justified when they bring } \\
\text { order and safety }\end{array}$ & 0.57 & 0.73 & 0.73 & 0.67 & 0.77 & 0.69 \\
\hline $\begin{array}{l}\text { Dictatorships are } \\
\text { justified when they bring } \\
\text { economic benefits }\end{array}$ & 0.52 & 0.68 & 0.70 & 0.66 & 0.72 & 0.67 \\
\hline Country average & 0.32 & 0.37 & 0.52 & 0.42 & 0.45 & 0.41 \\
\hline
\end{tabular}

Note Population estimates for proportion of responses for categories "agree" and "strongly agree" 


\subsection{Modeling Support for Authoritarian Practices: Concepts of Citizenship and Civic Knowledge}

The first model indicates that students with duty-based and comprehensive citizenship profiles show similar levels of support for authoritarian government practices, except for Chile, where duty-based students show a slightly higher level of support $\left(\beta_{\text {Chile }}=1.70, \mathrm{p}<0.05\right)$. Socially-engaged students show slightly lower levels of support for authoritarian practices than comprehensive students (between $\beta_{\text {Peru }}=-$ $0.75, \mathrm{p}<0,001$ and $\left.\beta_{\text {Peru }}=-1.37, \mathrm{p}<0.001\right)$. Monitorial students show slightly lower levels of support for authoritarian practices than comprehensive students in only two countries: $\beta_{\text {Chile }}=-2.20(\mathrm{p}<0.001)$ and $\beta_{\text {Mexico }}=-1.27(\mathrm{p}<0.001)$. Moreover, except for the Dominican Republic, anomic students show the lowest levels of support for authoritarian practices compared to comprehensive students (between $\beta_{\text {Colombia }}=-3.76, \mathrm{p}<0.001$, and $\beta_{\text {Mexico }}=-7.50, \mathrm{p}<0.001$ ). Figure 1 clearly shows these differences. Additionally, civic knowledge has a negative effect on support for authoritarian government practices, which implies that students with higher knowledge about civic rules, institutions, and the rule of law show lower support for authoritarian ideas (see Table 4).

The second model indicates that for students with the lowest levels of civic knowledge (terms that represent zero-knowledge), the differences between citizenship profiles are higher than in Model 1. For example, anomic students show lower levels of support for authoritarian practices than comprehensive students (between $\beta_{\text {Colombia }}$ $=-18.89, \mathrm{p}<0.001$ and $\left.\beta_{\text {Dominican }}=-32.17, \mathrm{p}<0.001\right)$. These are huge differences, representing more than two or three standard deviations. Interaction terms indicate that these differences are reduced as students increase their civic knowledge (see Table 4).

Overall, students with lower civic knowledge show higher support for authoritarian ideas. Moreover, civic knowledge interacts with citizenship profiles. Students with an anomic profile of citizenship show the lowest predicted levels of support for authoritarian practices in Chile, Colombia, Mexico, and Peru, while students with comprehensive citizenship profiles show the highest predicted value. The Dominican Republic is the exemption for this pattern. This country presents the lowest rate of anomic students, and this result can alter the estimations. In contrast, students with higher levels of civic knowledge show lower support for authoritarian practices independent of citizenship profile. As a result, considering higher levels of civic knowledge, different ways of conceiving norms of adult citizenship are inconsequential (see Fig. 1). 
Fig. 1 Predicted conditional levels of support for authoritarian practices. Notes Predicted levels of support for authoritarian practices, conditional to citizenship profiles, based on fitted Model 2 including interaction terms
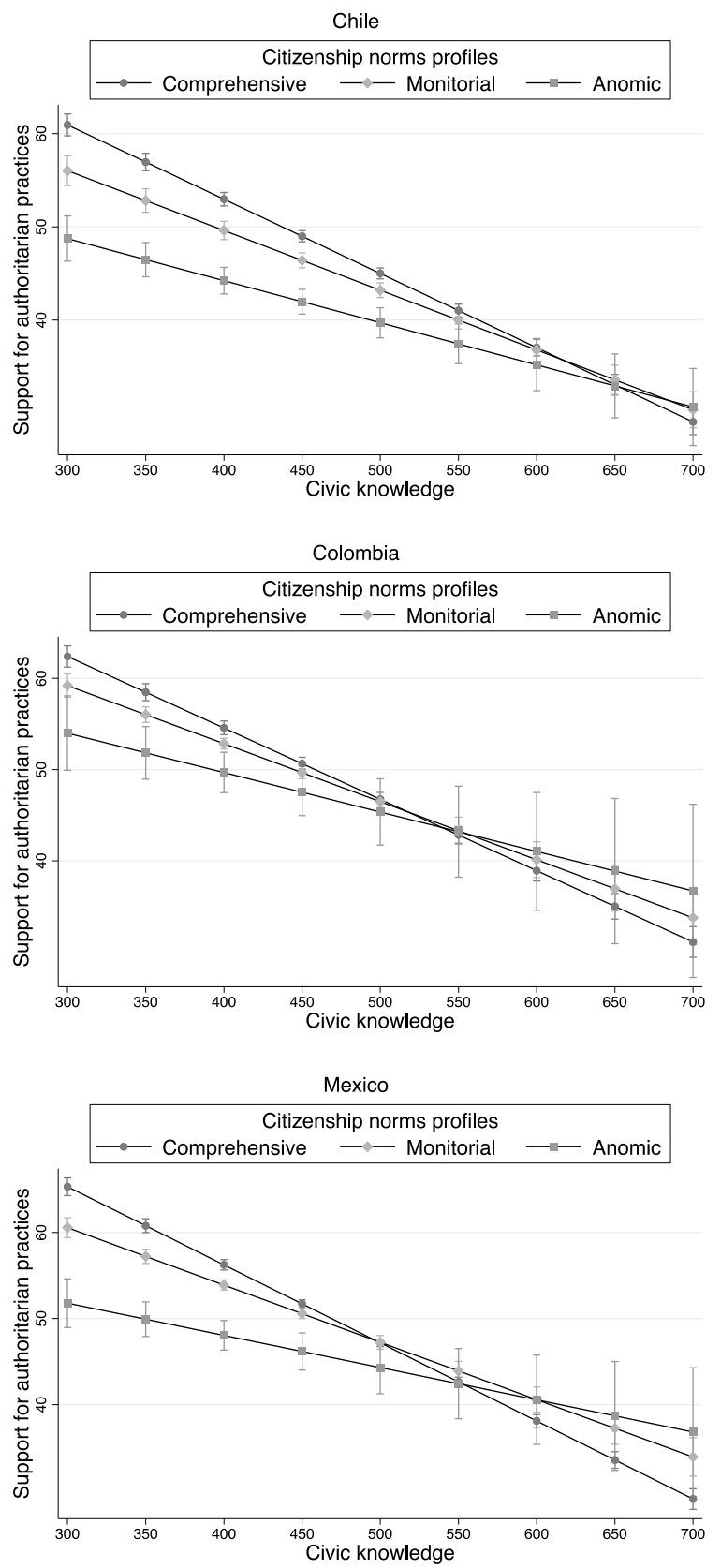
Fig. 1 (continued)
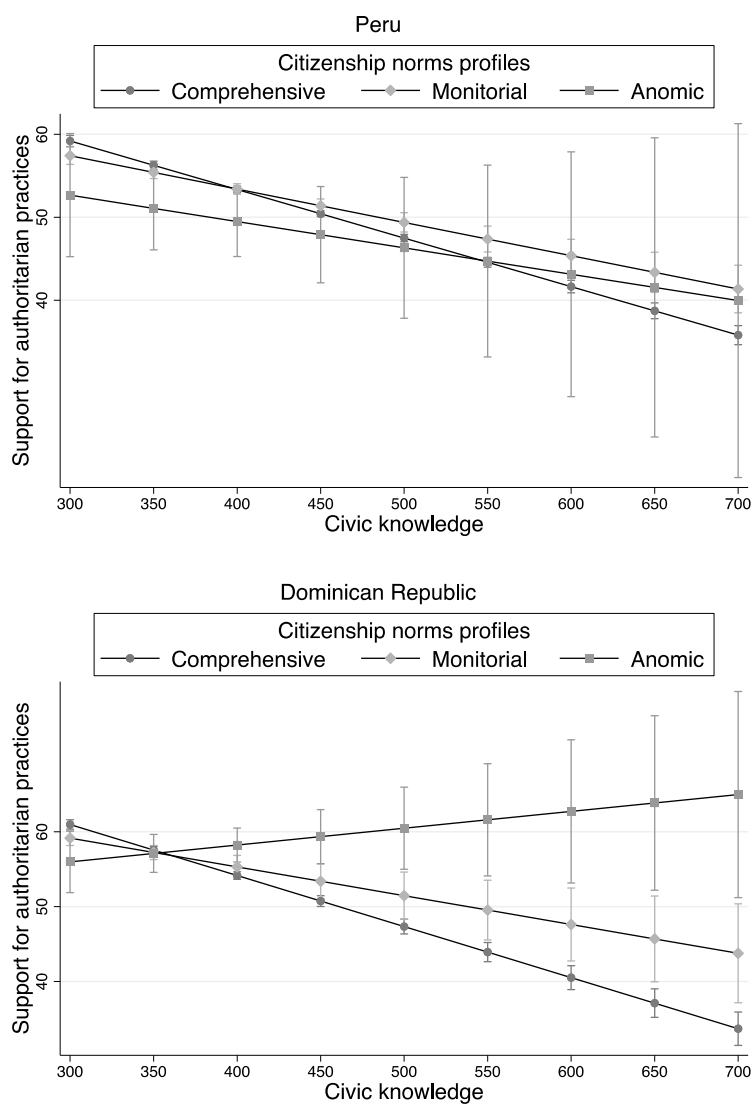

\section{Conclusion and Discussion}

This chapter shows that students from five Latin American countries participating in ICCS 2016 express worrying levels of support for authoritarian government practices. This pattern of results illustrates the difficulties facing the democratization of the region given its political culture. In particular, the younger generation's authoritarian beliefs represent an important obstacle.

In the best scenario, we highlight that most students reject authoritarianism, by expressing disagreement with the 11 authoritarian government practices presented. Those authoritarian government practices with the lowest support include making decisions without consulting; considering dissidents as enemies; dispensing with the law; enforcing their authority; and closing critical communications media. All of these practices receive between 22 and $29 \%$ of support, on average, among students. In Chile and Colombia, we observed the least support for these practices, with between 13 and $14 \%$ of students supporting at least one of these ideas, while students in Mexico and the Dominican Republic express the highest support (38\% in the 


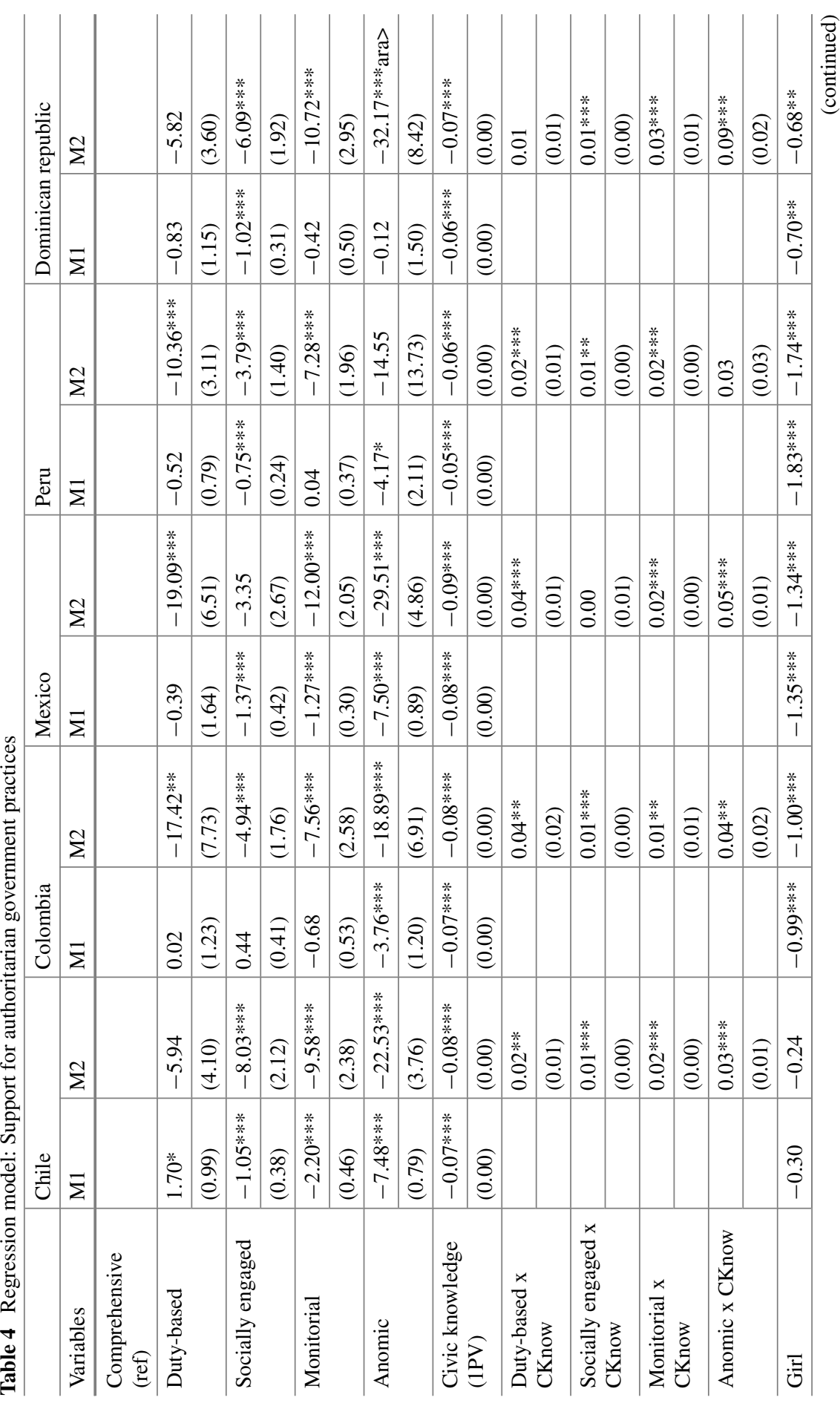




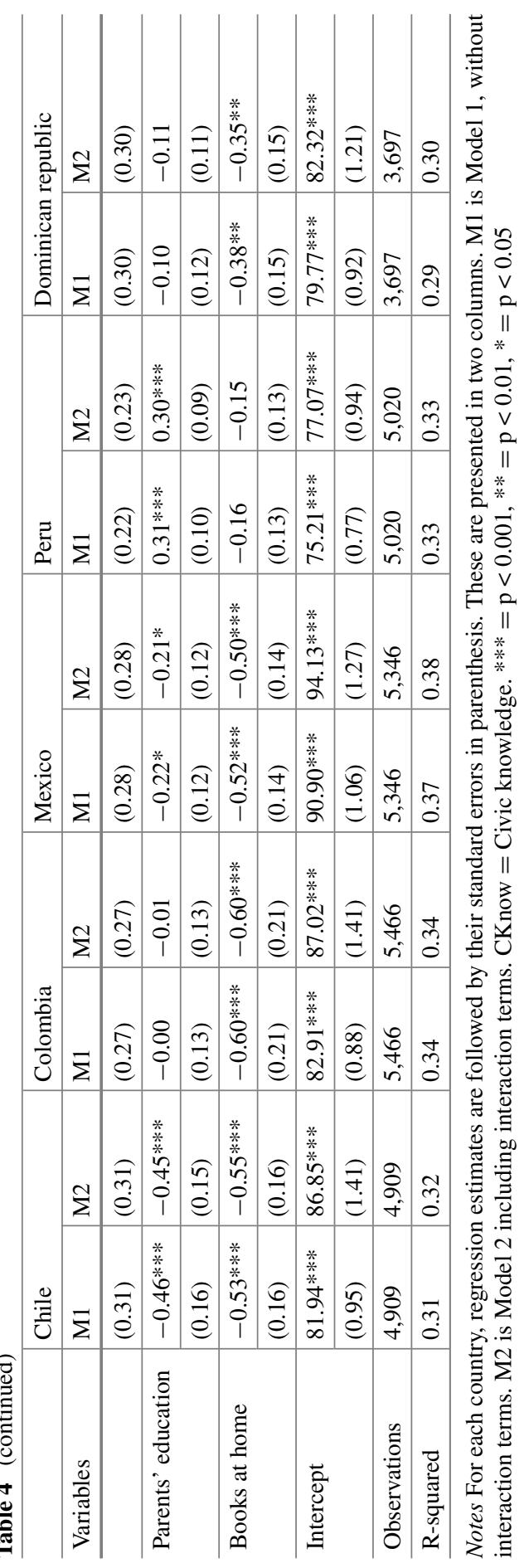


Dominican Republic). In the worst case, students support several of these authoritarian practices (between 38 and $69 \%$, on average), such as the possibility that governments and/or leaders could: dissolve parliament, avoid recognizing mistakes, overvalue the president's opinion, and justify dictatorships if it brings order, safety, and economic benefits. These results are similar to those for the adult population, which indicates consistent patterns. It seems that democratic and anti-democratic ideas are transmitted from one generation to another. These processes, not only in the transmission of democratic but also anti-democratic ideas, should be investigated further as part of an open and interesting debate.

The role played by citizenship profiles shows very interesting patterns. In general, different citizenship profiles imply different levels of support for authoritarian practices. Students with duty-based and comprehensive profiles show higher levels of support for authoritarian practices, while monitorial and anomic students are less likely to support authoritarian practices. This pattern of results is particularly marked when we considered the role of civic knowledge. The first step indicates that those with higher levels of knowledge are less likely to support authoritarian practices. In addition, civic knowledge moderates the differences in levels of authoritarian support among citizenship profiles. For instance, students with lower levels of civic knowledge show higher levels of support for authoritarian practices (above the international average) and show differences among citizenship profiles. Anomic and monitorial students show lower levels of support than duty-based and comprehensive students, but only among students with lower levels of civic knowledge. Those who reject the traditional norms of citizenship embrace, to a lesser extent, the authoritarian culture. In contrast, students with higher levels of civic knowledge show lower support for authoritarian ideas, and there are no differences between citizenship profiles.

These results highlight the role that education plays in citizenship. The acquisition of content and relevant information about the political system is important for the legitimacy of democracies and diminishes support for government practices that erode this very system. Civic knowledge protects young people from authoritarian ideas and moderates the effect of citizenship profiles. When students have information and knowledge, it only matters what they know, and less what they believe about citizenship norms. Nevertheless, when students do not have information and knowledge about the civic system, what students believe about citizenship, or in this case what they do not believe, is relevant. In a setting of poor information and knowledge, it seems that students' sense of duty is combined with authoritarianism. As Altemeyer (2003) indicates, supporters of authoritarianism adhere tightly to social conventions, and this seems particularly to be the case when students have low levels of civic knowledge. This idea is consistent with previous evidence about the authoritarian personality, which indicate that less informed/educated people (or in this case, people with less civic knowledge) tend to support authoritarian regimes or practices (Schulz et al. 2018c, 2011).

Considering one possible future scenario, in 15 years these young people will be formal citizens and those with little information about civic life may be more willing to support an authoritarian government, especially those with a normative conception of citizenship. Only those who better understand democracy would be less willing to 
support anti-democratic leaders. Any similarity between this scenario and the reality in some countries today is not the responsibility of the authors.

This chapter sheds light on how different conceptions of citizenship norms are linked with the delegitimization of democracy, as represented by support for authoritarian government practices. In addition, we focus on the role of acquisition of knowledge in protecting democracy from its threats: knowledge works as a vaccine against anti-democratic ideas. We need further research to better understand the different normative citizenship profiles in Latin American countries, especially in terms of how their flexibility/rigidity interacts with varying levels of civic knowledge.

Acknowledgements The authors would like to thank their research sponsors, the Chilean National Agency of Research and Development through the grants ANID/FONDECYT N ${ }^{\circ} 11190508$, ANID/FONDECYT $\mathrm{N}^{\circ} 1181239$, and the Center of Social Conflict and Cohesion Studies-COES ANID/FONDAP N ${ }^{\circ} 15130009$.

\section{References}

Adorno, T. W., Frenkel-Brunswik, E., Levinson, D. J., \& Sanford, R. M. (1950). The authoritarian personality. New York, NY: Harper.

Almond, G. A., \& Verba, S. (1989). The civic culture: Political attitudes and democracy in five nations. London, United Kingdom: Sage.

Altemeyer, B. (1996). The authoritarian specter. Cambridge, MA: Harvard University Press.

Altemeyer, B. (2003). What happens when authoritarians inherit the earth? A simulation. Analyses of Social Issues and Public Policy (ASAP), 3(1), 161-169. https://doi.org/10.1111/j.1530-2415. 2003.00020.x.

Altemeyer, B. (2008). The authoritarians. Ramona, CA: Cherry Hill Publishing.

Bolzendahl, C., \& Coffé, H. (2013). Are "good" citizens "good" participants? Testing citizenship norms and political participation across 25 nations. Political Studies, 61(SUPPL.1), 63-83. https:// doi.org/10.1111/1467-9248.12010.

Booth, J. A., \& Seligson, M. A. (1984). The political culture of authoritarianism in Mexico: A reexamination. Latin American Research Review, 19(1), 106-124. https://doi.org/10.2307/250 3299.

Coffé, H., \& van der Lippe, T. (2010). Citizenship norms in Eastern Europe. Social Indicators Research, 96(3), 479-496. https://doi.org/10.1007/s11205-009-9488-8.

Dalton, R. J. (2015). The good citizen. How a younger generation is reshaping American politics (2nd ed.). London, United Kingdom: Sage.

Dewey, J. (1989). Freedom and culture. New York, NY: Prometheus.

Gehlbach, H. (2015). Seven survey sins. Journal of Early Adolescence, 35(5-6), 883-897. https:// doi.org/10.1177/0272431615578276.

Haynes, J. (2003). Introduction the 'Third World' and the third wave of democracy. In J. Haynes (Ed.), Democracy and political change in the Third World (pp. 1-21). London, United Kingdom: Routledge.

Jennings, M. K. (2015). The dynamics of good citizenship norms. In T. Poguntke, S. Rossteutscher, R. Schmitt-Beck, \& S. Zmerli (Eds.), Citizenship and democracy in an era of crisis (pp. 93-111). London, United Kingdom: Routledge.

Köhler, H., Weber, S., Brese, F., Schulz, W., \& Carstens, R. (Eds.). (2018). ICCS 2016 user guide for the international database. Amsterdam, the Netherlands: International Association for the Evaluation of Educational Achievement (IEA). 
Lagos, M. (2003). Latin America's lost illusions: A road with no return? Journal of Democracy, 14(2), 163-173. https://doi.org/10.1353/jod.2003.0038.

Lipset, S. M. (1959). Some social requisites of democracy: Economic development and political legitimacy. American Political Science Review, 53(1), 69-105. https://doi.org/10.2307/1951731.

O'Donell, G. A. (1994). Delegative democracy. Journal of Democracy, 5(1), 55-69. https://doi.org/ 10.1353/jod.1994.0010.

PNUD. (2015). Desarrollo humano en Chile. PNUD Santiago, Chile: Los tiempos de la politización. Sartori, G. (1999). Elementos de teoría política [Elements of political theory]. Madrid, Spain: Alianza.

Schneider, S. L. (2008). The international standard classification of education (ISCED-97): An evaluation of content and criterion validity for 15 European countries. Mannheim, Germany: MZES, University of Mannheim.

Schulz, W., Ainley, J., Fraillon, J., Kerr, D., \& Losito, B. (2010). ICCS 2009 international report: Civic knowledge, attitudes, and engagement among lower-secondary school students in 38 countries. Amsterdam, the Netherlands: International Association for the Evaluation of Educational Achievement (IEA).

Schulz, W., Ainley, J., Friedman, T., \& Lietz, P. (2011). ICCS 2009 Latin American report: Civic knowledge and attitudes among lower-secondary students in six Latin American countries. Amsterdam, the Netherlands: International Association for the Evaluation of Educational Achievement (IEA).

Schulz, W., Ainley, J., Fraillon, J., Losito, B., \& Agrusti, G. (2016). IEA International Civic and Citizenship Education Study 2016 assessment framework. Cham, Switzerland: Springer.

Schulz, W., Ainley, J., Cox, C., \& Friedman, T. (2018a). Students' perceptions of public institutions and government. In W. Schulz, J. Ainley, C. Cox, \& T. Friedman (Eds.), Young people's views of government, peaceful coexistence, and diversity in five Latin American countries. IEA International Civic and Citizenship Education Study 2016 Latin American report (pp. 27-38). Cham, Switzerland: Springer. https://doi.org/10.1007/978-3-319-95393-9_3.

Schulz, W., Ainley, J., Fraillon, J., Losito, B., Agrusti, G., \& Friedman, T. (2018b). ICCS 2016 international report: Becoming citizens in a changing world. Cham, Switzerland: Springer.

Schulz, W., Carstens, R., Losito, B., \& Fraillon, J. (Eds.). (2018c). ICCS 2016 technical report. Amsterdam, the Netherlands: International Association for the Evaluation of Educational Achievement (IEA).

Seligson, M. A., \& Booth, J. A. (1993). Political culture and regime type: Evidence from Nicaragua and Costa Rica. The Journal of Politics, 55(3), 777-792. https://doi.org/10.2307/2132001.

Statacorp. (2016). Stata user guide: Release 14. College Station, TX: Stata Press.

Stevens, D., Bishin, B. G., \& Barr, R. R. (2006). Authoritarian attitudes, democracy, and policy preferences among Latin American elites. American Journal of Political Science, 50(3), 606-620. https://doi.org/10.2307/3694237.

van Deth, J. W. (2007). Norms of citizenship. The Oxford Handbook of Political Behavior. https:// doi.org/10.1093/oxfordhb/9780199270125.003.0021.

van der Heijden, H.-A. (2014). Handbook of political citizenship and social movements. Northampton, United Kingdom: Edward Elgar Publishing Inc.

Dr. Daniel Miranda is a Research Scientist at Measurement Center MIDE UC, Pontificia Universidad Católica de Chile. He also participates in the Centre for Social Conflict and Cohesion Centre (COES). He holds a doctoral degree in Sociology and a master's degree in Social Psychology at the Pontificia Universidad Católica de Chile. His undergrad of Psychology was obtained at the University of Talca. Their interests are focused on youth political participation, political inequalities, political socialization, intergroup relations, intergroup attitudes, public opinion research, and quantitative methods. 
Catalina Miranda is a Research Assistant at Centro de Estudios de Políticas y Prácticas en Educación (CEPPE-UC). He holds a degree in Political Science and Master in Sociology from the Pontificia Universidad Católica de Chile. His research work focuses on expectations of political participation, attitudes towards minorities and citizen education.

Loreto Muñoz is a Senior Project Manager in applied social research at Datavoz. She holds a degree in Sociology and Master's candidate in Survey design and analysis (MDAES) from the Pontificia Universidad Católica de Chile. His research work focuses on survey methodology, gender gap in civic education, behavior and attitudes toward citizenship.

Open Access This chapter is licensed under the terms of the Creative Commons AttributionNonCommercial 4.0 International License (http://creativecommons.org/licenses/by-nc/4.0/), which permits any noncommercial use, sharing, adaptation, distribution and reproduction in any medium or format, as long as you give appropriate credit to the original author(s) and the source, provide a link to the Creative Commons license and indicate if changes were made.

The images or other third party material in this chapter are included in the chapter's Creative Commons license, unless indicated otherwise in a credit line to the material. If material is not included in the chapter's Creative Commons license and your intended use is not permitted by statutory regulation or exceeds the permitted use, you will need to obtain permission directly from the copyright holder. 